tion," one cannot but feel that, in certain cases, it might prove an operation of value.

Upon the question of vaccine therapy in nasal and otitic suppurations the author does not say very much, and is (rightly) cautious in his remarks.

It is noted that Quinlan's forceps are now referred to (p. 342) in discussing the clearing of the epipharyngeal space in adenoid operations.

The whole surgery of the nose and naso-pharynx is very adequately treated, and offers quite a wealth of operative procedures, the greater number of which are very well illustrated.

In the section dealing with the pharynx and fauces much space is devoted to the tonsils, and numerous operations are described. Among them we note one attributed to Sluder, which appears to be identicil with that recently described by Whillis and Pybus. The remarks upon lingual varix need revision, but less so than does the description of the laryngoscopic picture of malignant neoplasm of the larynx (p. 554). This was pointed out in a former review in this Journal, and it is remarkable that the reference to Semon's law remains here, and that, in the section devoted to paralysis of the recurrent laryngeal nerve (p. 514), Semon's name is not even mentioned.

One would think the bringing out of a third edition would have afforded the author opportunity of profiting by the criticism of his reviewers, but he appears to have taken only a partial advantage of this opportunity. He has corrected the spelling of Ruault's name, but Siebenmann still appears as Siebermann, and the need of revision in such places as have just been noted is very patent. It is a pity, too, that the valuable work of British otologists upon labyrinth operation. should have received so little notice.

The discussion of diseases of the ear is adequate but not exhaustive. The author has modified the so-called Heath operation, and we note with approbation that he has personally had rare occasion to use the grafting operation "as his cases usually become covered with epidermis in as short a time as is claimed by Ballance after the use of Thiersch grafts." This is probably the experience of most otologists at the present day. It is to be noted that ossiculectomy, in the author's opinion, gives a very small percentage of cures.

An excellent section deals with the surgery of the facial nerve.

The general arrangement and appearance of the book are excellent, and the plates, especially the coloured ones, form a most valuable addition to the work.

Macleod Yearsley.

\title{
BOOK RECEIVED.
}

Handbuch der speciellen Chirurgie des Ohres und der oberen Luftwege. By Drs. L. Katz, H. Preysing, and F. Blumenfeld. With coloured plates. $1 \mathrm{Bd}$. Liefer: 4 and 5 . Würzburg: Curt Kabitsch (A. Stuber's Verlag), 1911. 


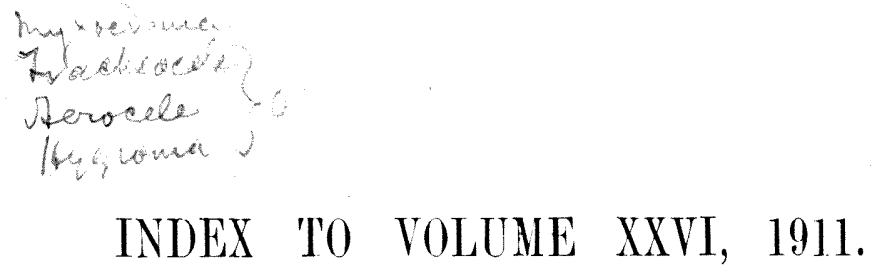

\section{SUBJECTS.}

Abductor paralysis, see Cords, vocal.

Acoustic nerve, see Auditory nerve.

Adductor paralysis, see Cords, vocal.

Adenoids (J. Symington) anæsthesia for removal of (F. Guyot, Lautmann, Rupprecht)

and the hypophysis (Citelli)

$614,382,544$

in school children (Macleod Yearsley)

intra-nasal extension of (A. Meyer) . _ . . . . 437

- operation for complications of (S. M. Bourack, Grossard and

Kaufmann) . . . $\quad . \quad 4 \quad 495-544,614,383$ respiratory re-education of (Labouré) $\quad . \quad 614$

— with albuminuria, etc. (J. M. O'Meara) $\quad \cdot \quad \cdot 613$

Alæ nasi, collapse of, ætiology and operative cure of (M. Halle) $\quad$. 348

Alcohol intoxication, experimental (R. Bárány) $\quad . \quad$. $\quad .652$

American Laryngological, Rhinological, and Otological Society

President's Address (Logan) .

$101,151,271,317,653$

\section{Rhinological and Otological Society :}

. 101

Anæsthesia, nasal reflex during (J. Blumfeld)

476,536

Antrostomy, nasal, burr for (S. Hastings) . $\quad . \quad$. $\quad 217$

Antrum, maxillary, anatomy of (J.P. Schaeffer) : $\quad . \quad$. $\quad 327$

\begin{tabular}{llll}
- & 3 & 272 \\
\hline
\end{tabular}

$\longrightarrow$ disease of, unusual (J. P. Clark) $\quad . \quad . \quad 50$

$\begin{array}{llll}- & & & 663\end{array}$

- operation on, blocking of nasal duct (D. McKenzie) $\quad \cdot \quad 215$

\begin{tabular}{lll}
- osteoma of (Phillip) & 483 \\
\hline radical operation on (W. L. Ballenger) & $\cdot$ & 153
\end{tabular}

- simple growths of (Kahler) $\quad . \quad 1.489$

- sarcoma of (H. J. Davis, O. Freer) $\quad$ (H. J. Davis) $\quad 34,440$

- suppuration of, followed by sarcoma (H. J. Davis) $\quad . \quad 34$

\begin{tabular}{l}
- suppuration of, in childhood (H. J. Davis) \\
\hline tooth in (H. Tilley)
\end{tabular}$\quad \begin{array}{r}35 \\
\hline\end{array}$

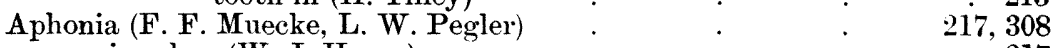

— in a boy (W. J. Horne) . $\quad . \quad . \quad . \quad . \quad 217$

- recurrent (G. Catheart) . $\quad$ • $\quad$. $\quad$. $\quad 142$

Arseno-benzol, see Salvarsan.

Arytænoid abscess, primary (Curtil) _ . $\quad$. $\quad$. $\quad 329$

Asthma, endoscopic treatment of (W. Freudenthal) . $\quad$. $\quad .537$

- nasal (Grossmann, Jay) : $\quad$ - $\quad$ : $\quad$. $\quad$. $\quad 269,493$

- (P. Watson Williams) • $\quad 617$

Auditory nerve, action of salvarsan upon (O. Beck, Benario, Desneux

and Dujardin, Gander and Guggenheim) . 317, 608, 499, 500, 501

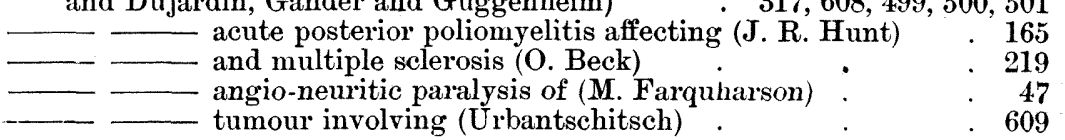


Austrian Otological Society

Autokinesis interna and externa (ron Stein)

$154,312,608, \stackrel{\text { PAGE }}{650}$

Brain, complication of frontal sinusitis (J. S. Fraser, J. D. Lithgow) $\quad 45$

Exposure of, through nasal sinuses, etc. (Onódi) $\quad . \quad 435$

- topography of (Onódi) . . . . . . . . 435

- see also Frontal lobe, Temporo-sphenoidal lobe, etc.

British Medical Association, Birmingham Meeting, July, 1911

Bronchiectasis due to foreign body, removal (H. Tilley) 561, 599,626 et seq.

Bronchoscopy (P. Watson-Williams and A. J. M. Wright) : 525

for foreign bodies (H. Tilley, D. C. Green, Casselberry) $211,276,319,525$

- treatment of asthma by (W. Freudenthal) . . .537

Bronchus, foreign body removed from (H. Tilley) $\quad . \quad \vdots \quad \vdots 211$

Caloric tests of posterior canal (Cheatle and Jenkins) _ . $\quad .92$

Canals, semicircular, external, fistula of (Bondy, W. Milligan, L. Sewell)

- posterior, exposed (Cheatle and Jenkins)

$154,90,54$

Cancer, disappearance, fistula of (S. Scott)

92

Carotid artery, internal, case of (R. H. Woods)

Cerebellum, abscess of (Bárány, J. S. Barr, Ruttin, W. Milligan)

$313,375,314,87,88$

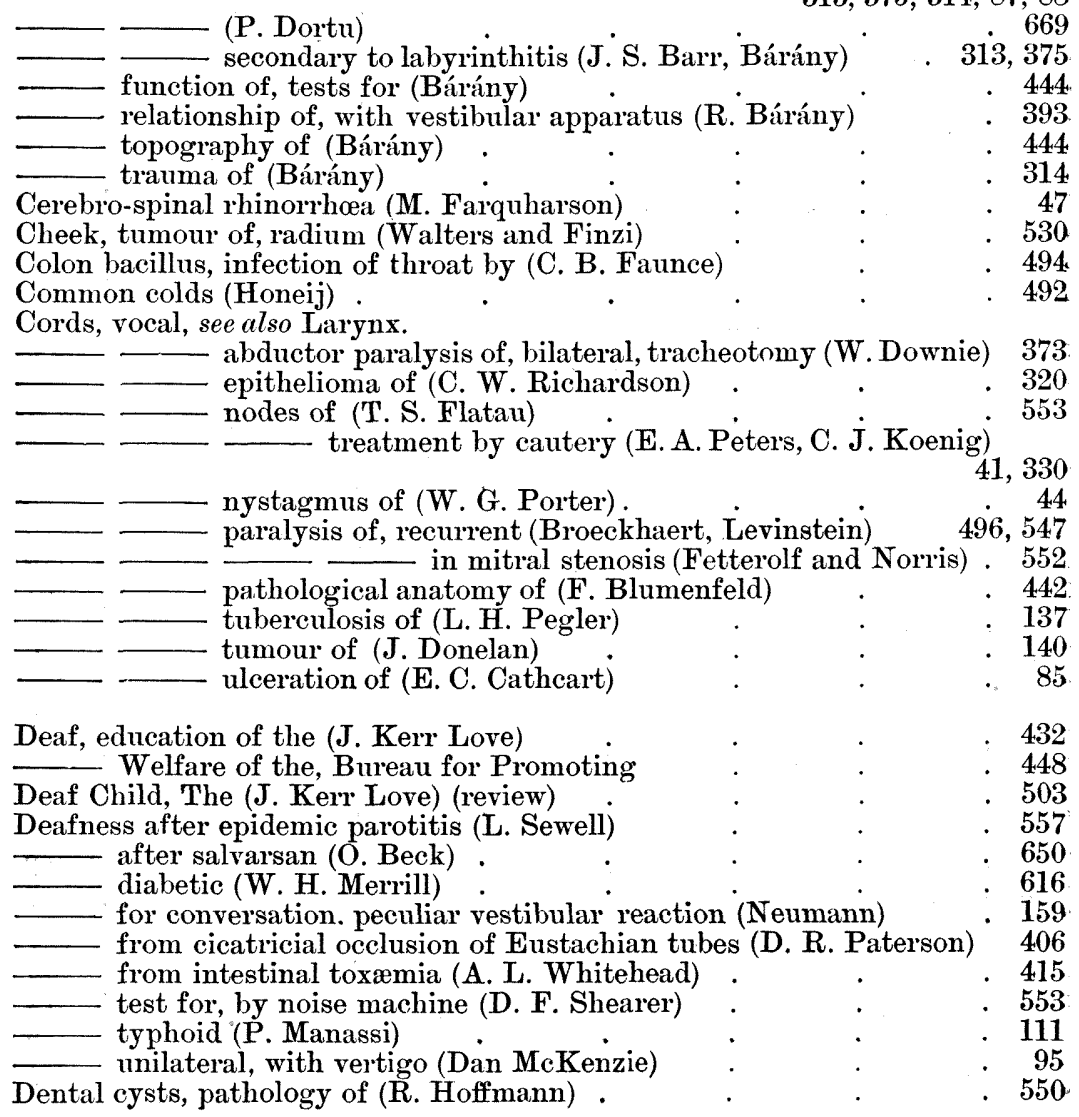


Diphtheria antitoxin, death following (S. F. McKeen) . $\quad{ }_{665}^{\text {PAGE }}$ carriers (A. G. Macdonald) . . . . $\quad 384$

Diphtheritic paralysis (A. Love) . $\quad . \quad 5 \quad . \quad 565$

Ear and Throat Department, Royal Infirmary, Edinburgh, Reports for

$\begin{array}{cccc}\text { year } 1909 & 57 \\ \text { Ear, comparative anatomy of (W. J. Horne) } & \cdot & \cdot & 409\end{array}$

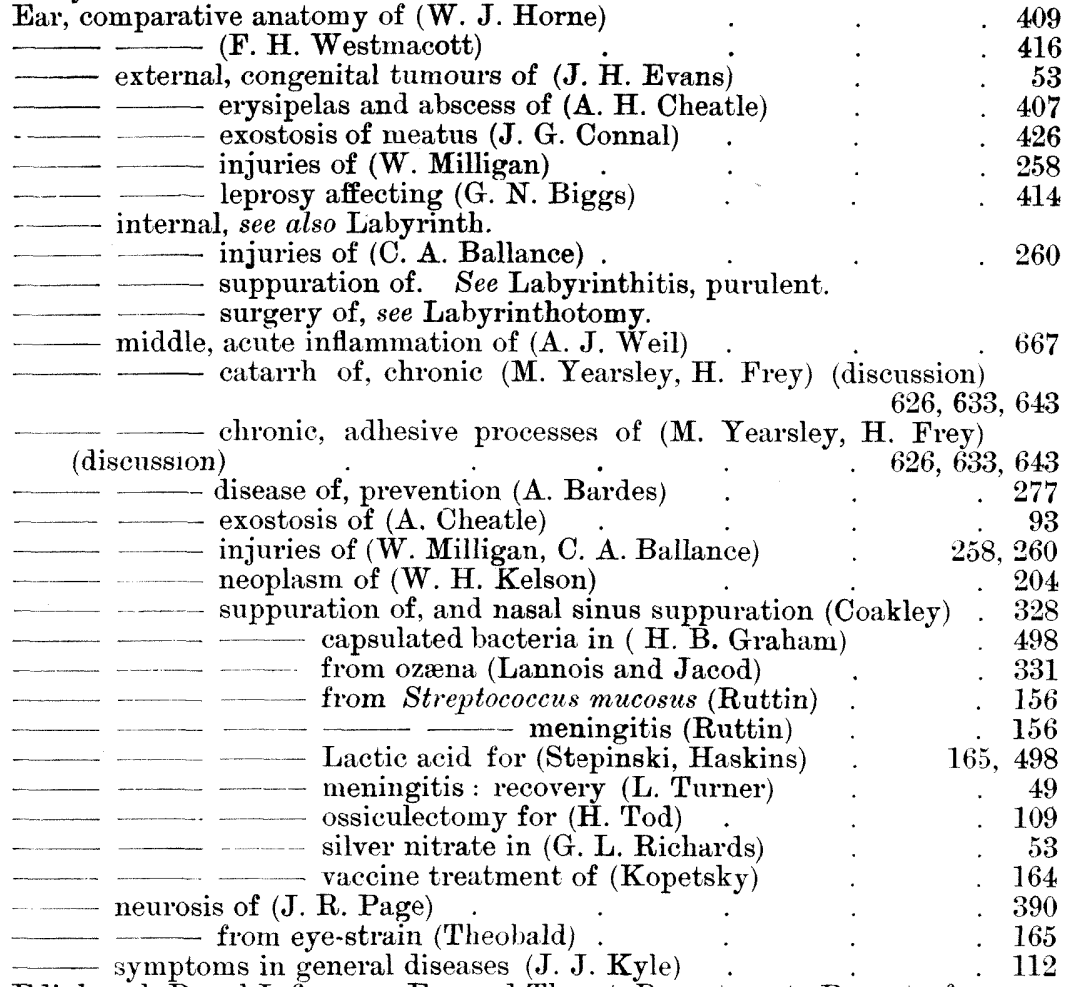

Edinburgh Royal Infirmary, Ear and Throat Department, Reports for the year 1909

Ehrlich-Hata Remedy, see Salvarsan.

Emphysema, subcutaneous, of neck, after removal of tonsils (B.D.Parish) 275

Endoscopy, see Bronchoscopy, etc.

Epiglottis, epithelioma of (N. Patterson) . . . . . . . 143

Ethmoid, bony cyst of (J. A. Thompson) : $\quad: \quad \cdot \quad \cdot 611$

See also Turbinal, middle.

— carcinoma of (J. S. Barr) . . . . . . $\quad 376$

_- operation on ; orbital cellulitis after (A. J. M. Wright) $\quad .529$

- paralysis of third nerve after (A. J. M. Wright) $\quad .530$

Sarcoma of, bilateral (W. Downie) . . . 372

Ethmoiditis, non-suppurative (W. B. Chamberlain) . $\quad . \quad 50$

$\begin{array}{lr}\text { visual fields in (G. F. C. Wallis) } & 252 \\ \text { Eustachian tube, deafness from cicatricial occlusion of (D. R. Paterson) } & 53\end{array}$

\begin{tabular}{lll} 
Eustachian tube, deafness from cicatricial occlusion of (D. R. Paterson) & 53 \\
\hline development of (J. E. Frazer) & 53
\end{tabular}

Extra-dural abscess from frontal sinusitis (J. S. Fraser) . $\quad . \quad 45$

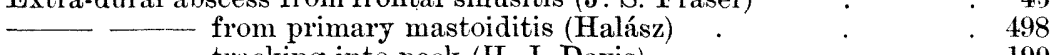

- tracking into neck (H. J. Davis) $\quad \cdot \quad \cdot \quad \cdot \quad \cdot 199$

— - with speech disturbances (Rudloff) . . . . . 164

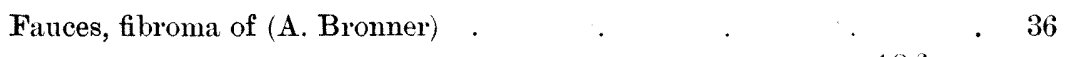


Fibrolysin in otology (M. Yearsley)

Fistula-symptom (R. Bárány) $\quad . \quad$. $\quad$. $\quad . \quad 312$

Foreign bodies, see under Regions.

French Society of Largyngology, Otology and Rhinology $\quad . \quad 481$

Frontal bone, necrosis of (W. Downie) . . . . 374

Frontal lobe of brain, otitic abscess of (P. Watson-Williams) $\quad . \quad 423$

Frontal sinus, see Sinus, frontal.

Glossitis, chronic (P. Watson-Williams) . $\quad . \quad 5 \quad$. $\quad 529$

Halle, University Aural Clinic at . . . . . 204

Hay-Fever and Paroxysmal Sneezing (Vaso-Motor Rhinitis) (Eugene S. Yonge) (review)

Hay-fever, prophylactic inoculation for (L. Noon) . $\quad . \quad 611$

Hearing after radical mastoid (C. M. Brown) ‥ . 447 effect of tobacco upon (H. O. Reik). . . $\quad 390$ of railway employees (V. Grazzi) . . . . . $\quad 668$ physiology of (G. E. Shambaugh) . $\quad . \quad$. $\quad . \quad 387$

Hexamethylenamine, elimination of (Barton) $\quad . \quad . \quad . \quad 278$

Hints for the General Practitioner in Rhinology and Laryngology (Johann Fein) (review) .

Hungarian Society of Physicians, the Royal ; Section-Rhino-Laryngology

Hypophysis, see Pituitary body.

Influenza of nose and throat, recurrent (G. L. Goodale)

International Congress of Medicine at Budapest, Laryngological Section

$145,268,378,488$

Otological Sections; Officers

$145,268,378$
logical and Laryngo-Rhinological Congress, Third, at Berlin $\quad$. $\quad 218,280$ Otological Congress, Ninth

Ionic medication (R. W. MacKenna)

Journal of Laryngology, Rhinology, and Otology, The 113

Jugular bulb, operations on (G. Tiefenthal) . . . 525

- vein, internal, ligature ; rupture of carotid (F. Nuernberg) . $\quad 554$

Labyrinth, see also Ear, internal.

effect of head-injury on (C. A. Ballance, Stenger)

fistula of (Barany, Bondy, W. Milligan, S. Scott, L. Sewell)

necrosis of (F. H. Westmacott)

$312,154,90,201,54$

suppuration of (Dortu)

$\begin{array}{ll}- & \text { surgery of (Alexander, S. J. Kopetzky) . . . } \quad 556,498\end{array}$ syphilis of, in secondary stage (Hintze) salvarsan in (O. Beck)

Labyrinthine vertigo, treated by operation (G. J. Jenkins)

\begin{tabular}{rrr}
\hline suppuration of (Dortu) &. & 669
\end{tabular}

Labyrinthitis, latent (J. Harper) - . 553 $\begin{array}{llllll}\text { - pathology of (Max Görke) . } \quad \text {. } & \text {. } & \text {. } & 398\end{array}$ purulent (P. D. Kerrison) . . . . . 553

___ $\quad$ and cerebellar abscess (J. S. Barr) $\quad . \quad . \quad . \quad 375$ - recovery (Ruttin) . . . 314 fatal (J. S. Fraser) . . . 46

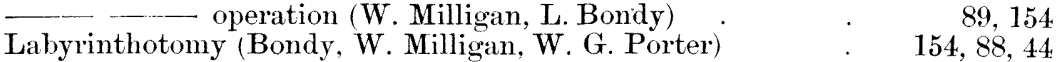

Laryngeal nerve, superior, injection of alcohol into (L. Turner) . 48 Laryngitis, chronic (W. Howarth) . . . 304 treatment of (T. J. Faulder) 
Laryngitis, typhoid (M. Paunz)

Laryngo-tracheal stenosis, treatment of (discussion) (V. Uchermann, etc.)

Laryngology, retrospect of

Laryngoscopy, direct (E. F. Ingals)
Larynx, see also Cords, vocal.

- cancer of (N. Patterson, L. H. Pegler, C. W. Richardson, P.

Watson-Williams) .

$143,139,320,208,526$

- pathology (F. Blumenfeld, E. Schmiegelow)

442,52

\begin{tabular}{|c|c|c|c|c|}
\hline 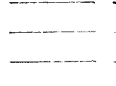 & $\ldots$ & operative treatment of (Koschier) & & 489 \\
\hline & $\ldots$ & party-wall of (L. H. Pegler) & & $\begin{array}{l}546 \\
214\end{array}$ \\
\hline & $-\ldots$ & radium for (Molinié) & & 486 \\
\hline & $-\ldots$ & slow evolution of (Moure) : & . & 485 \\
\hline & - & stenosis, complete, from (StClair Thomson) . & & 310 \\
\hline & & recurrence in glands, disappearance $(\mathrm{R} . \mathrm{H}$. Woo & & 495 \\
\hline & $-\infty-$ & thyrotomy (Fournié) & & \\
\hline & compar: & ative anatomy of (J. G. Wilson) . & 103, & 386 \\
\hline & congeni & ital malformation of (M. Farquharson) & 列 & 48 \\
\hline & diseas & of; for diagnosis (A. J. Wright) . & . & 78 \\
\hline & epitheli & loma of, see Larynx, cancer of. & & \\
\hline & fibroma & of (F. Tratman) & & 667 \\
\hline & sulg & $\begin{array}{l}\text { body in (H. Dencker) } \\
\text { tor for (W. J. Horne) }\end{array}$ & & 443 \\
\hline & intubat & ion of, conditions ten years after (B. R. Shurly) & & 386 \\
\hline & & omy (Citelli) . & & 441 \\
\hline & 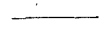 & and fixation of tubes (Bonain) & & 486 \\
\hline & - & instruments for (H. P. Mosher) & & 152 \\
\hline & lupus o & f (Kelson, J. Safranek) & & \\
\hline & myasth & avis affecting (S. Hastings) & & 40 \\
\hline & necroti & c inflammation of ( $\mathbf{E}$. Oppikofer) & & 667 \\
\hline & neoplas & $f(F$ Powoll) & & 144 \\
\hline & papillor & ma of (M. Farquharson, Dan McKenzie) & & 141 \\
\hline & - & R. Claoué) . & & 386 \\
\hline & - & long-continued (F. R. Packard) & & 323 \\
\hline & - - - & subglottic (W. Downie) & . & 373 \\
\hline & - & unusual (Carter) . & & 442 \\
\hline & 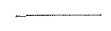 & paralysis of recurrent (Broeckhaert, Levinstein) & & \\
\hline & rigid re & esistances of (Scanes Spicer) & & 25 \\
\hline & stenosi & $s$ of (Uchermann, Thost) & & 145 \\
\hline $\mathrm{C}^{-}$ & 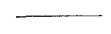 & epithelioma (StClair Thomson) & & 310 \\
\hline & $\overline{a_{1} \cdot 1}$ & for (Sieur and Rouvillois) & & 484 \\
\hline & syphili & s of & & 321 \\
\hline & $\overline{\text { tuberct }}$ & (Avellis. Safranek, Gerbe & &, 502 \\
\hline & & $\begin{array}{l}\text { chronic (C. A. Parker) } \\
\text { chents }\end{array}$ & &, 210 \\
\hline 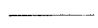 & $\underline{\ldots}$ & (C. Horsford) & & 43 \\
\hline & $\underline{-}$ & direct laryngoscopy for (Claoué) & & 486 \\
\hline & 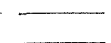 & of alcohol (Logar & & 48 \\
\hline$\ldots$ & $\bar{\square}$ & in a boy (W. J. Horne) & & 309 \\
\hline & - & $\begin{array}{l}\text { regional anwsthesia in (Sleur and Rouvillols) } \\
\text { simulated by foreign body (H. Dencker) }\end{array}$ & & 443 \\
\hline & 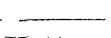 & treatment of (Dundas Grant, P. Watson-Williar & G. S. & \\
\hline & Hett, an & id discussion) . : & $1,574,58$ & \\
\hline & & $\begin{array}{l}\text { trichloracetic acid in (K. Sytschow). } \\
\text { ventricles of, "stripping." in horses (F , F }\end{array}$ & & $\begin{array}{l}615 \\
205\end{array}$ \\
\hline Lep & Dr., & A Motses (1. & & 126 \\
\hline Leî & & Victor Urbantschitsch & & 56 \\
\hline & & (G. N. Big & & 414 \\
\hline
\end{tabular}


Lingual thyroid, see Thyroid gland, lingual.

Lip, chancres of, epidemic (J. F. Schamberg)

Lucae, the late Professor (Dundas Grant)

Lumbar drainage in meningeal infection (Wicart)

Mackenzie tonsillotome, improved (H. E. Jones) . . . 335

Mastoid bone, cholesteatomatous cavity in (F. H. Westmacott) diploëtic infantile; unilateral suppuration Cheatle) .

(A. $\mathrm{H}$.

Mastoiditis, acute, Bier's method in (G. C. Catheart).

Reynolds) in infancy (G. Mathewson)
intra-cranial complications of

(L. Turner and F. E. Reynolds) primary (Halász) . scarlatinal, extensive bone disease from (H. J. Davis)

Maxilla, superior, malformation of, unusual (H. Tilley)

Mediastinum, tumour of, death by asphyxia (Coakley)

"Medical Annual," The, 1910 (review) 1911 (review)

Membrana tympani, rupture of, in telephone operator (Veis) .

Ménière's syndrome, treated by operation (G. J. Jenkins)

Meningitis from middle-ear suppuration (D. W. Drury)

Nasal duct, see Naso-lacrymal duct.

- obstruction, see Nose, obstruction of.

Naso-lacrymal duct, window.resection of (West) . . . . 328

Naso-pharyngoscope (Holmes, Emerson) $\quad . \quad$. $\quad . \quad$. 494

Naso-pharynx, cancer of (C. F. Theisen) $\quad \cdot \quad \cdot \quad \cdot \quad \cdot \quad \cdot 317$

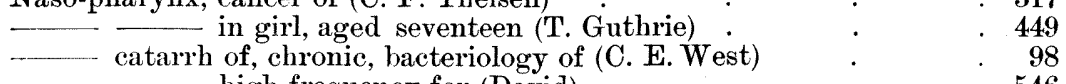

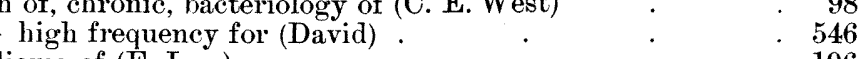

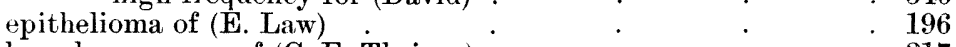
lympho-sarcoma of (C. F. Theisen) $\cdot \quad \cdot \quad \cdot \quad \cdot 317$ polypus of (H. J. Davis, M. Farquharson) $\quad \cdot \quad \cdot \quad \cdot \quad 36,48$ fibro-mucous (Moure)
fibrous (W. B. Chamberlain, Walker Downie, W. H.

Kelson, W. A. Wells)

- syphilitic obliteration of (Dan McKenzie) $540,372,84,539$ 216

Nerves, cranial, action of salvarsan upon (Benario, etc.) . 499 et seq. 


\section{Index.}

Nerves, cranial, in tabes dorsalis (W. Williams) $\quad \begin{array}{r}\text { PAGK } \\ 5.59\end{array}$

See also Vestibular apparatus.

Neurasthenia, nasal phenomena of (C. P. Grayson) . . 101

Neuro-recurrence after salvarsan (Benario, Desneux and Dujardin H.

Gander)

See also Vestibular apparatus.

Nodes, singer's', galvano-cautery for (E. A. Peters, C. J. Koenig) 41, 330

Nose and throat, diseases of the (StClair Thomson) (review) . . 671

cancer of (W. Stuart Low) . . . . . . $\quad .50$

$\begin{array}{lll}- & & \\ \end{array}$

— treatment of (J. Price Brown) . . . . 325

catarrh of, acute, see Rhinitis.

deformity of, treated by paraffin (W. Downie) . 371

by transplanting costal cartilage (W. W. Carter,

D. C. Greene) . . . 273, 441 diseases of, injuries of the head and (Ziem) . $\quad . \quad 127$

379

to oculo-orbital diseases (Baumgarten, Coffin, Cun-

ningham, Frankenberger, StClair Thomson, Wallis) 160, 272, 338, 439

irrigation for (Guthberlet) . . . $\quad . \quad 276$

lateral wall of, development of (J. P. Schaeffer) . $\quad 662$

leprosy of (H. J. Davis) . . $\quad 31$

leukæmia causing abscesses of (Tunis) . $\quad 385$

lupus of, ionic medication for (R. W. MacKenna) . $\quad 611$

- Rouge's operation for (M. Farquharson) . . 47

myxoma of (Hajek and Polyak) . . 150

neoplasm of (W. J. Horne) . . . . . 309

neurasthenic phenomena in (C. P. Grayson) . 101

obstruction of, effects (R. Palleine) _ . $\quad$. $\quad 549$

physiology of (J. Adam) . . 288

polypus of ; choanal (Láng) 4492

492

379

Nose, syphilis of (Lautmann) salvarsan in (G. N. Biggs, Gerber, Safranek) 
Nose, vestibule of, primary chancre of (N. Patterson) . $\quad$ PAGE

- - retention cyst of (Logan Turner) . $\quad . \quad 48$

Nystagmus, vestibular, compensatory (E. Ruttin) . $\quad . \quad 609$

explanation of (L. K. Guggenheim) . $\quad$. $\quad .388$

Ocular symptoms produced by nasal disease (E. Baumgarten, L. A.

Coffin, H. H. B. Cunningham, StClair Thomson, O. Frankenberger,

G. F. C. Wallis), (discussion) 160,612, 272, 388, 439, 531, 242, 511, 531

CEsophago-gastroscope (W. Hill) . . . . 82, 134, 525

Esophagoscope with expanding blades (W. Hill) $\quad . \quad$. $\quad$. 82

Esophagoscopy, experiences (S. H. Large). . . . . 330

Esophagus, cancer of (W. Hill, C. Watson-Williams) $\quad$. $\quad 307,143$

- Finzi) radium in (C. Watson-Williams, C. Hope and N.S. temporary cure ( $\dot{W}$. Hill)

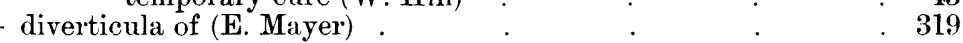

foreign body in (N. Patterson) $\quad . \quad 1 \quad$. $\quad . \quad 79$

spasmodic stricture of (J. G. French) _ . . . . 37

Optic neuritis and ophthalmoplegia externa from sphenoidal disease

(H. J. Davis) benefited by operation (H. Smith)

Orbital cellulitis after ethmoidal operation (A. J. M. Wright) . $\quad$. 529

Ossiculectomy, value of (Hunter Tod) . . 109

Otic element of arctic whale (F. H. Westmacott) $\quad . \quad$. $\quad .416$

Oto-larnygology, the teaching of (S. MacCuen Smith and discussion) . 658

Otosclerosis (G. Brühl, O. Mayer) $\quad$. $\quad$. $\quad . \quad 294,496$

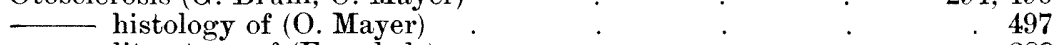

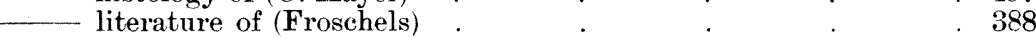

—_ pathology and situation of (G. Ferreri) $\quad . \quad$. $\quad 109$

- traumatic (E. Ruttin)

Otology, retrospect of . $\quad . \quad \ldots \quad . \quad . \quad 20$

Otorrhcea, see Ear, middle, suppuration of.

Ouston (T. G.), obituary notice . . . . . . $\quad$. 560

Ovo-œsophago-gastric tube, permanent styletted (W. Hill) $\quad . \quad$. 307

Ozæna, see Rhinitis, atrophic.

Palate, deficiency of, congenital (W. Downie) deformity of, with displaced pituitary body (A. Tweedie) $\quad . \quad 80$ endothelioma of, treated with radium (J. G. French) . $\quad .209$ epithelial pearls of, and tumours (Di Colo) . $\quad . \quad 491$

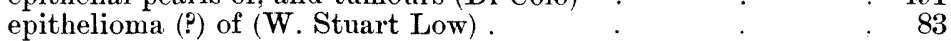

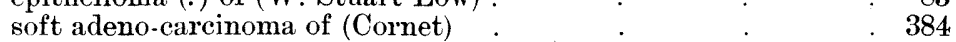
paralysis of (W. S. Syme) : $\quad . \quad . \quad 431$ perforation of (W. J. Horne) . . $\quad .309$

\begin{tabular}{llr} 
Paraffin, injection of, for nasal deformity (W. Downie) &. &. \\
\hline
\end{tabular}

Parotid, cystic adenoma of (W. Stuart-Low) $\quad . \quad . \quad 82$

$\begin{array}{llll}\text { Pemphigus (W. Watson-Williams) } & \cdot & . & 528\end{array}$

Periotic bones of fossil Cetacea (W. J. Horne) $\quad \cdot \quad . \quad 409$

Peritonsillar abscess, death from (S. W. Prowse) . $\quad . \quad$. $\quad . \quad 664$

\begin{tabular}{llll} 
& $\cdot$ & $\cdot$ &. \\
\hline
\end{tabular}

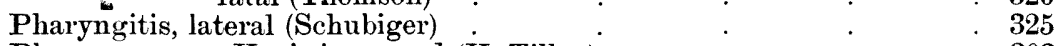

Pharyngoscope, Hay's improved (H. Tilley) $\quad . \quad$. $\quad . \quad 303$

Pharynx, cancer of (M. Farquharson, P. R. W. de Santi) : $\quad$ 47, 307

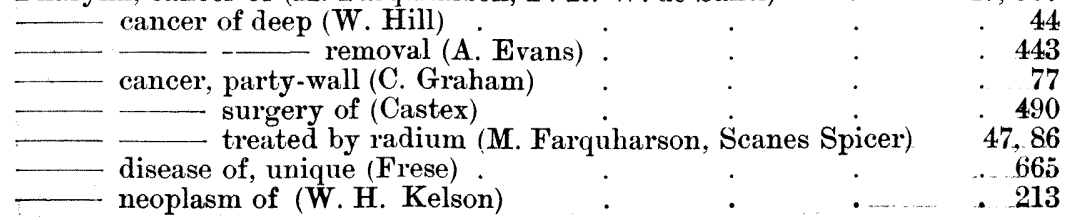


Pharynx, papilloma of (E. C. Catheart) from pyorrhœa (L. H. Pegler)

Phonation, centres for (Katzenstein)

Phonetics, see also Voice, the (Zwaardemaker and Boumann).

Pituitary body displaced with deformed palate (A. Tweedie) neoplasms of, operation, intra-nasal route (N. H. Pierce) surgery of (L. Löwe)

Poliomyelitis, epidemic (W. S. Bryant)

Pulmonary tuberculosis, treatment of (C. A. Bucklin)

Pyorrhoea alveolaris, vaccine treatment of (Williams)

Quinine and urea hydrochlorate as local anæsthetic (G. Fletcher Ingals)

Quinsy, see Peritonsillar abscess.

"Radiography of the Mastoid Process and of the Nasal Accessory Sinuses, Photographic Atlas of " (Joseph Beck) (review)

Radium for tumour of cheek (Walters and Finzi) - in diseases of the nose and throat (Freudenthal, T. G. Ouston)

___ in laryngeal cancer after thyrotomy (Molinié).

- - in esophageal cancer (W. Hill, Finzi and Hope) in pharyngeal cancer (M. Farquharson)

Rectal feeding, value of (W. L. Brown)

Reflex neuroses of ear, nose, pharynx (W. S. Bryant, J. R. Page) $\quad .390$

Remedies, a Practical Guide to the Newer (J. M. Fortescue Brickdale) (review)

Reports for the year 1909 from the Ear and Throat Department of the Royal Infirmary, Edinburgh (A. Logan Turner).

Retropharynx, embryonic cysts of (Onódi) .

Rhinitis, atrophie (J. Adam, J. S. Fraser, and F. E. Reynolds) and otitis media (Lannois and Jacod).

- vaso-motor, see Rhinorrhoa, vaso-motor.

Rhino-laryngology and general medicine (H. Arrowsmith) . . 390

Rhinology, retrospect of. $\quad . \quad . \quad . \quad . \quad 16$

Rhinorrhoa, cerebro-spinal (M. Farquharsoin) $\quad \cdot \quad$. $\quad . \quad 47$

— vaso-motor (Mignon) . . . . . . 482

Rib, cartilage of, transplantation of, into nose (D. C. Greene) . $\quad . \quad 273$

"Roaring" in horses, operation for (F. Hobday) . . . 205

Rosenmuiller's fossa and the middle ear (M. Yearsley) . . 331

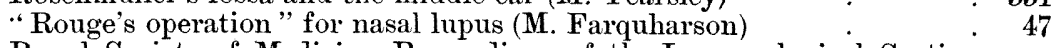

Royal Society of Medicine, Proceedings of the Laryngological Section 
“606," see Salvarsan.

Salivary glands, diseases of (discussion) _ . 476

Salvarsan (Benario, etc.) .

syphilitic, improved by (O. Beck)

. 499

$317,608,650$

. 316

- effect upon labyrinth (G. Alexander, Benario, etc.)

in congenital syphilis (J. L. Bunch)

in diseases of larynx (G. Avellis)

in syphilis of nose (G. N. Biggs, Gerber, Safranek)

instruments for injection of (Lieven)

Treatment of Syphilis by (review)

Scleroma, clinical aspect (Neumann)

distribution of (Irsä. Schrötter)

Scottish Otological and Laryngological Society

Sea-sickness, causation of (Bárány)

Semicircular canals, see Canals, semicircular, and also Vestibular

apparatus.

Semon Lectureship in Laryngology

389,499 et seq.

. 503

501

414,502

. 86

. 112

. 488

488

44, 371, 424

. 157

$\begin{array}{llll} & . & . & .\end{array}$

Septum nasi, see Nose, septum of.

Singer's nodes, see Cords, vocal.

Sinus frontal, endothelioma of (N. Maclay) . . . . . 301

$-\quad$ intra-nasal drainage of (F. Ingals) $\quad . \quad 579$

-

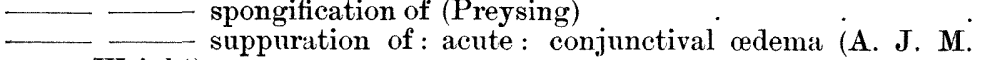

Wright).

549

W. S. Syme) Killian's operation for (J.S. Fraser, R. Fullerton,

treatment of (J. S. Barr, J. Moore, Stuart-Low,

StClair Thomson, Weil, P. Watson-Williams (discussion)

$354,355,356,357,376,380$ with cerebral involvement (J. D. Lithgow) $\quad 45$

Watson-Williams operation (Watson-Williams) $\quad 526$

with extra-dural abscess (J. S. Fraser) . . 45

with necrosis of frontal bone (W. Downie) : 374

surgery of (T. G. Gallaher)

lateral, thrombosis of (J. G. Connal, J. Kerr Love, W. C. Nourse,

J. W. Wood)

$427,426,94,253$

sigmoid, see Sinus, lateral.

sphenoidal, suppuration of, eye symptoms (H. J. Davis, G. F. C.

Wallis)

Sinuses, accessory, exostoses of (H. P. Mosher)

33,242 disease of, and ocular symptoms (Baumgarten, L. A.

Coffin, Cunningham, Frankenberger, StClair Thomson, G. F. C.

Wallis, Watson-Williams) ․ $\quad$. 160, 272, 242, 338, 439, 511

- suppuration of, and acute otitis media (Coakley)
-1 in scarlet fever (T. Hubbard).

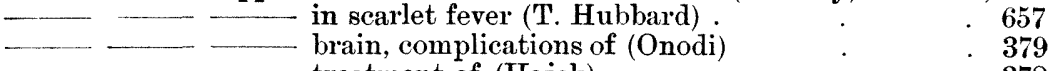

_- treatment of (Hajek) . $\quad .378$

Tinuccine treatment (Burkett and Meakins) . $\quad 163$

Sinusitis, anterior nasal visual fields in (G. F. C. Wallis) . $\quad .511$

Sixth cranial nerve, paralysis of, otitic (L. Leto) $\quad . \quad$. $\quad .616$

Specialists, education of (C. M. Cobb) $\quad: \quad 278$

Speziellen Chirurgie des Ohres, etc., Handbuch der (Drs. Katz, Preysing and Blumenfeld) (review) . . . . . 503

Spheno-palatine ganglion, syndrome of neurosis of (G. Sluder) $\quad .151$

Submucous resection, see Nose, septum of.

Surdus in Search of his Hearing: An Exposure of Deafness Quacks (Evan Yellon) (review) 
Syphilis, Treatment of, by the Ehrlich-Hata Remedy (review) .

- see also Salvarsan.

Syringo-bulbia affecting nose, ete. (A. B. Kelly)

Syringomyelia (Schrötter)

Tabes dorsalis, cranial nerves in (W. Williams) $\quad . \quad$. $\quad 559$

Teeth, the, and diseases of mucous membranes (W. K. Sibley) . 437

Telangiectasis of mouth, etc. (J.Safranek) . . . . 433

Temporal bone, types of fracture of (A. H. Cheatle, G. J. Jenkins) $\quad$. $\quad 267$

Temporal lobe, see Temporo-sphenoidal lobe.

Temporo-sphenoidal lobe, abscess of, (Pommerehne) . $\quad$. $\quad 669$

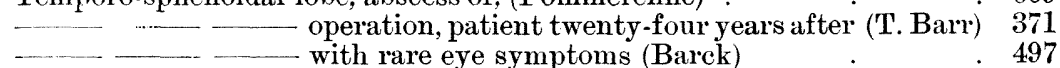

- with rare eye symptoms (Barck)

tumour of, misleading symptoms (Ruttin)

423

609

Thrombo-kinase, hæmostatic (L. W. Strong). $\quad . \quad . \quad 560$

Thyro-fissure, see Thyrotomy.

Thyro-lingual cyst, removal of, acute thyroidism (H. J. Davis) - 33

Thyroid cartilage, wounds of, cicatrisation of (Strazza) . 147

gland, diseases of, and the upper respiratory tract (R. S. Burt) . 558 suppuration of (I. Bahri)

\begin{tabular}{rrr}
- lingual (G. W. Badgerow, Bertein and Gellé) &. & 142,550 \\
\hline
\end{tabular}

\begin{tabular}{rrr}
- lingual (G. W. Badgerow, Bertein and Gellé) &. & 142,550 \\
\hline
\end{tabular}

\begin{tabular}{rrr} 
lingual (G. W. Badgerow, Bertein and Gellé) &. & 142,550 \\
\hline
\end{tabular}

Thyrotomy, cicatrisation after (Strazza) . $\quad . \quad$. 147 for papilloma (F. R. Packard, W. Downie) . $\quad . \quad 323,373$

$\begin{array}{llll}\text { Tobacco deafness (Reik) } & . & 390\end{array}$

Tongue, black (C. H. Knight) . . . . $\quad 324$

Tonsil, cancer of, cured by operation (M. H. Richardson) . $\quad$. 665 sarcoma of, in a child (L. C. Cline) . _ . . . . 665

Tonsils, enucleation of (J. S. Fraser) $\quad . \quad . \quad . \quad 668$

$\begin{array}{llll}\text { faucial, cancer of (P. R. W. de Santi) } \quad \cdot \quad & \cdot & 307\end{array}$

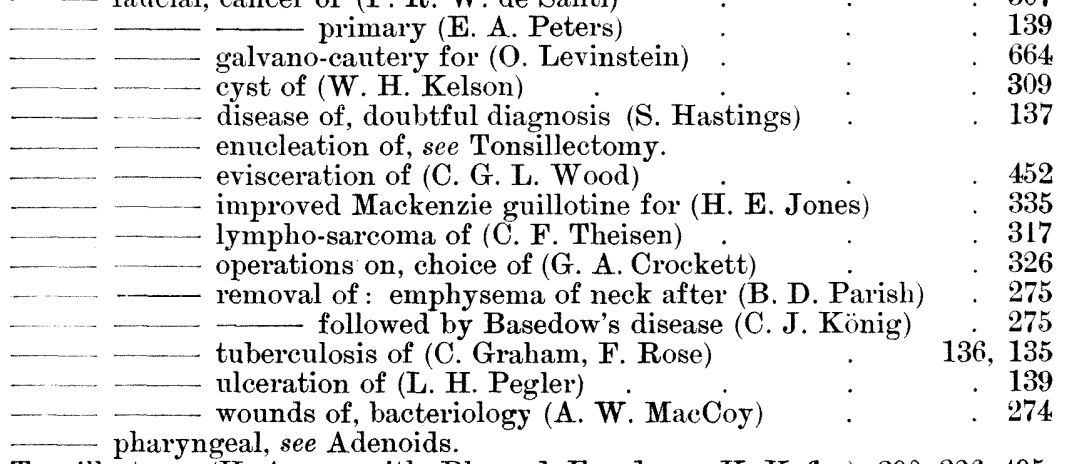

Tonsillectomy (H. Arrowsmith, Blegvad, Freedman, K. Kofler) 390, 326, 495, $\begin{array}{ll}\text { hæmorrhage after (H. A. Barnes) . } \quad . \quad & 325 \\ \mathbf{2 7 4}\end{array}$

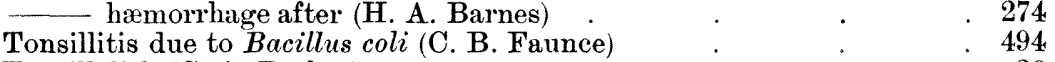

Tonsillolith (C. A. Parker) $\quad$. $\quad$. $\quad .36$

Trachea, fatal pressure on, by tumour (C. G. Coakley) $\quad \cdot \quad \cdot \quad 322$

$\begin{array}{lll}\text { foreign body in (Clark and Richardson) } & \cdot & 276\end{array}$

\begin{tabular}{llll}
- gumma of, death from (McCardie) &. &. &. \\
\hline
\end{tabular}

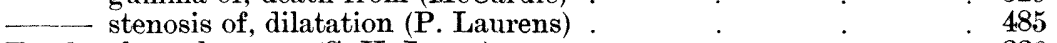

Tracheo-bronchoscopy (S. H. Large) $\quad . \quad$. $\quad 330$

Tracheo-laryngostomy for stenosis (W. Hill) $\quad . \quad . \quad . \quad 304$

Trauma in relation to otology (discussion). $\quad . \quad . \quad . \quad 258$

Treatment of Syphilis by the Ehrlich-Hata Remedy, The (Dr. J.

Bressler) (review) 
Turbinal bone, middle: cyst of (H. Gaudier, P. Watson-Williams) PAGE Turbinated bodies and sinuses, function of ( $\mathrm{J}$. Adam)

- hypertrophy of, treated by electrolysis (M. Bresgen) . $\quad 268$

Tympanum, see Ear, middle.

Typhoid deafness (P. Manasse) . . . . . . 111

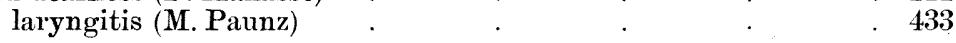

Urea-hydrochlorate and quinine as local anæsthetic (E. F. Ingals) . 106

Uvula, pedunculated growth on (H. Tilley)

Vaccine treatment (discussion)

- of accessory sinusitis (Burkett and Meakens) . $\quad 163$

- of middle-ear suppuration (Kopetsky) $\quad 164$

- _ of pyorrhoa alveolaris (Williams) . $\quad . \quad 552$

- - of scarlatinal rhinitis (Kolmer and Weston) . $\quad .662$

Vertigo, acute, case of (H. J. Davis) 199

labyrinthine, non-infective, operation for (G. J. Jenkins) . 411

- researches (von Stein) . . . 445

treated through Eustachian tube (E. M. Holmes) . $\quad . \quad 668$

Vestibular apparatus damaged by salvarsan (O. Beck) $\quad$. $\quad 316,317$

See also Neuro-recurrence. effect of salvarsan upon (G. Alexander) . . $\quad 389$

- hyper-activity of, in tumour (Urbantschitsch) . . 609

V relationship with cerebellum (R. Bárány) . . . 393

Vestibular reactions, effects of removal of parts of brain upon (Baner and Leidler) $\quad . \quad 6 \quad$. $\quad . \quad 6 \quad$. $\quad 669$

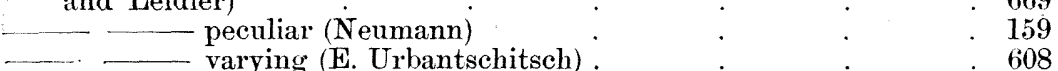

See also Nystagmus, vestibular, and Canals, semicircular.

Vision, impairment of, from intra-nasal disease (E. Baumgarten) $\quad . \quad 160$

Visual fields in anterior nasal sinusitis (G. F. C. Wallis) . $\quad 511$ in sphenoid and ethmoid sinusitis (G. F. C. Wallis) . 242

See also Ocular symptoms, etc.

Voice, The Abuse of the Singing and Speaking, etc. (E. J. Moure and E.

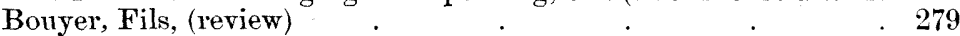

See also Phonetics.

Wire saw in radical mastoid (V. S. Stein) . $\quad . \quad$. $\quad$. 123

X-rays, see Radiography.

\section{AUTHORS.}

ADAM (James), atrophic rhinitis. hearing after mastoid operation odema of face polypi from inferior turbinals turbinal and sinus function

ALEXANDER (G.), labyrinth surgery salvarsan

Arrowsmith (H.), septal papilloma tonsil enucleation

Avelurs (Georg), salvarsan

Badgerow (Geo. W.), lingual thyroid

BAHRI (Ismet), thyroiditis

Ballance (C. A.), injuries of ear

BALLENGER (W. L.), antrum operation

BÁRÁNY, alcohol intoxication (Robt.), cerebellar abscess . 
BírÁNy (Robt.), cerebellum and vestibular apparatus sea-sickness

tests for cerebellar function trauma of cerebellum

BARCK, brain abscess

BARDES (A.), prevention of ear disease

BARIL (G.), regional anæsthesia

Barnes (H. A.), tonsillotomy

BARR (J. Stoddart), cerebellar abscess ethmoidal cancer frontal sinus operation

BARR (Thos.), temporo-sphenoidal abscess

BARTON, hexamethylenamine

BaUer (J.), and Leidler (R.), vestibular reflexes

BAUMGARTEN, early ozæna

270

BAUMGARTEN (E.), impairment of vision, ete.

BECK (J. C.), mastoid operations. salivary glands

ВЕск (Oscar), deafness after salvarsan multiple sclerosis salvarsan

Bertein (P.), and Gelié (E.), lingual thyroids

BENARIO, neuro-recurrence after salvarsan .

BigGs (G. N.), leprosy salvarsan

BLACK (N. M.), nasal stenosis

Blegvad, tonsillectomy .

BLUMENFELD (Felix), laryngeal cancer

Blumfeld (J.), nasal reflex

BonaIN, intubation

BONDY, labyrinthitis

BoUraCk, adenoid operations

Bresgen (M.), electrolysis

BRINDEL, synechiæ of nose

Bronner (Adolph), faucial fibroma

Brown (Clayton M.), radical mastoid

Brown (G. V. J.), maxillary readjustment .

Brown (W. Langdon), rectal feeding

BRÜHL (Gustave), otosclerosis

BRYANT (W. Sohier), epidemic poliomyelitis reflex neuroses

Bucklin (C. A.), pulmonary tuberculosis, etc.

BUNCH (J. S.), salvarsan

Burkett (H. S.), and Meakins (J. C.), vaccine treatment

160,612

CARTER (W. W.), laryngeal papilloma transplantation of bone, etc.

Casselberry (W. E.), bronchoscopy

CAstex, pharyngeal cancer

CATHCART (E. C.), acute mastoiditis papilloma of pharynx recurrent aphonia ulceration of vocal cord 
Cheatre (A. H.), and Jenkins (G. J.), exposed posterior semicircular canal

CHIARI, ethmoidal fibroma

Crtelli, adenoids and the hypophysis intubation

Claoú́ (R.), papilloma of larynx

laryngeal tuberculosis

Clark (J.P.), maxillary antrum disease and Rrcharoson (O.), foreign body in trachea

Chine (L. C.), sarcoma of tonsil

COAKLEY (C. G.) mediastinal tumour sinus suppuration, etc.

Coвв (C. M.), education of specialists

CoLo (Di) palatal tumours

CONNAL (J. Galbraith), exostosis of ear lateral sinus thrombosis

Coffin (L. A.), sinusitis and eye symptoms

CoRnet, epithelioma of palate

Crockett (E. A.), tonsil operations

CUNnINGHAM (H. H.), nose and eye

CURTIL, arytænoid abscess

David, high frequency

DAvis (H.J.), extra-dural abscess

- mastoiditis

_._. maxillary antrum suppuration in childhood

nasal leprosy

naso-pharyngeal polypus

sarcoma of antrum

- thyro-lingual cyst vertigo

De Santi (P.R. W.), cancer of pharynx

Delavan (D. B.), motor-car

DENCKER (H.). foreign body in larynx

DESNEUX and DUJARDIN, neuro-recurrence after salvarsan

Donetan (J.), nasal speculum

- swelling of vocal cord

Dortu (P.), cerebellar abscess

DownIE (Walker), bilateral abductor paralysis - congenital deficiency of palate

DownIE (Walker), ethmoidal sarcoma

- naso-pharyngeal polypus.

…necrosis of frontal bone

- - paraffin injections

Duvergie (J.) and BaIN (A.), sporotrichosis

Evans (Arthur), pharyngeal cancer

Evans (J. Howell), congenital auricular tumours

PAGE

FABRI (E.), iodo-thiosinamine

Farquharson (Malcolm), choanal polypus

...- cerebro-spinal rhinorrhœea . epithelioma of pharynx

- lupus of nose

_- papilloma of larynx paralysis of acoustic nerve

Faulder (T. Jefferson), chronic laryngitis

Faunce (C. B.), colon bacillus tonsillitis

FErN, resection of septum 
FetTerolf and NorRis, recurrent paralysis

Finzi and HoPe (C. W. M.), cesophagoscopy and radium $\quad \cdot \quad \cdot 52$

Frata U (T. S.), singers' nodes . . . . . . $\quad . \quad 553$

Fourní, cancer of larynx $\quad . \quad . \quad . \quad . \quad . \quad 218$

Frankenberger (O.), ocular disturbances, etc. $\quad . \quad \quad \quad . \quad$. $\quad 439$

Fraser (J. S.), enucleation of tonsils $\quad . \quad$. $\quad . \quad .663$ frontal sinusitis, extra-dural abscess _. . $\quad 45$

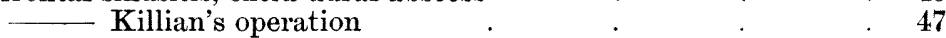
purulent labyrinthitis $\quad 46$ and ReynoLDs (F. E.), ozæna . $\quad . \quad 169$

Frazer (J. E.), development of Eustachian tube . . . . $\quad . \quad 53$

Freedman, tonsillectomy $\quad . \quad \ldots \quad . \quad . \quad . \quad . \quad 495$

Freer (O.), antral sarcoma . . . . . . . 440

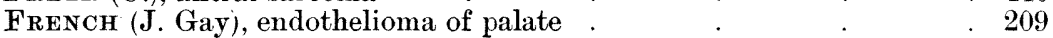
lateral sinus thrombosis . . . $\quad 520$

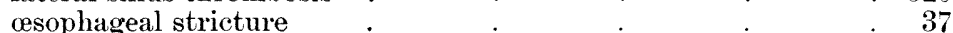

Frese (Prof.), unique disease of mouth . . . . . . $\quad$. $\quad 665$

Freddenthal (Wolff), asthma . . . . . . . $\quad .537$ intra-cranial complications $\quad . \quad 0 \quad$. $\quad . \quad 379$

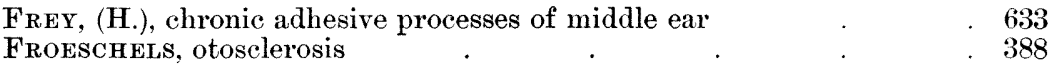

GAllaher (T. G.), frontal sinus operation . . . . . 656

Gardiner (W. T.), statistical tables _. . 114

Gavder (H.), middle turbinal cyst $\quad . \quad$. $\quad . \quad$. $\quad .493$

- and GUGGENHEIM (H.), salvarsan . $\quad . \quad$. $\quad .501$

GERBER, salvarsan . . . . . . 502

GILL (Richard), retro-pharyngeal abscess . $\quad . \quad$. $\quad . \quad 384$

GOODALE (J. L.), influenza $\quad . \quad$. $\quad . \quad . \quad 105$

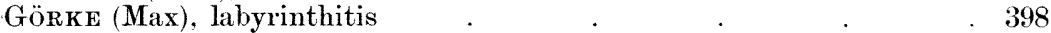

Gratam (Cecil), pharyngeal cancer . . . $\quad . \quad 77$ - tonsillar tuberculosis . . . . . . 136

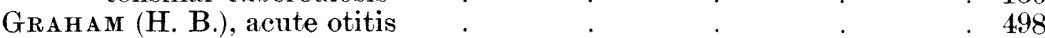

Gra NT (Dundas), laryngeal tuberculosis . $\quad$. $\quad$. $\quad .561$ Prof. Lucae . . . 281 $\begin{array}{lll}\text { (reviews) } & \cdot & 54,55,56,112,167,223,278,279,332,448,503\end{array}$

Grayson (C. P.), neurasthenia . 101

GrazzI (V.), hearing of railway employés : $\quad \cdot \quad \cdot \quad \cdot \quad \cdot 668$

GreEN (D. Crosby), bronchoscopy . $\quad 276$ - transplantation of rib, etc. 273

Grossard and KaUFmann, adenoidectomy $\quad . \quad$. . . $\quad$. 383

Grossman N, nasal asthma $\quad . \quad . \quad . \quad . \quad 268$

GUGGENHEIM (L. K.), vestibular nystagmus $\quad . \quad$. $\quad 388$

Gutberlet (W.), nasal irrigator $\quad . \quad$. $\quad 276$

GUThRIE (Thos.), cancer of naso-pharynx . $\quad . \quad 449$

GUYot (F.), anæsthesia for adenoids $\quad . \quad$. $\quad . \quad 614$

HAJEK, sinus suppuration $\quad . \quad$. $\quad . \quad$. $\quad .378$

\begin{tabular}{llll} 
& \\
\hline
\end{tabular}

Halísz (H.), extra-dural abscess . $\quad . \quad$. $\quad . \quad 4 \quad . \quad 498$

HaLLE (Max), alæ nasi.

HARPer (Jas.), latent labyrinthitis $\quad \cdot \quad \cdot \quad \cdot \quad \cdot \quad . \quad 553$

HASKIN (W. H.), suppuration of middle ear $\quad . \quad$. 498

Hastings (Somerville), burr for nasal antrostomy $\quad . \quad$. $\quad . \quad 217$ myasthenia gravis . 40

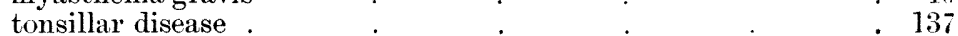

HEATH (C. J.), mastoid operation . $\quad . \quad$. . . 417

Hewd (R. Johnson), salivary glands $\quad 476$

HETr (G. Secombe), laryngeal tuberculosis $\quad$. $\quad$. $\quad$. $\quad 582$ 
HILl (Wm.), cancer of œesophagus

PAGE cancer of pharynx

nasal tuberculosis

csophagoscope with expanding blades

cesophago-gastroscopy

tracheo-laryngostomy

and Herschell (G.), nesophago-gastroscopy

Hintze (K.), labyrinth syphilis

HobDa Y (F.), ventricle-stripping, ete.

Hoff ManN (R.), maxillary cysts

Holmes (E. M.), cure of vertigo

-__- naso-pharyngoscope

HoNEIJ, common colds

HOR NE (W. Jobson), aphonia

-_ fossil periotic bones

-__n insufflator

- ne neoplasm of nose

_- perforation of soft palate

tubereulosis of larynx

HorsForD (C.), laryngeal tuberculosis

Howarth (Walter), chronic laryngitis

HUBBARD (Thos.), scarlatinal sinus suppuration

HunT (J. Ramsay), poliomyelitis, etc.

43,307

. 44

. 145

82

$82,134,307$

304

525

616

205

550

668

494

492

217

409

309

309

309

309

43

304

657

165

INGaLs (E. Fletcher), direct laryngoscope

536 frontal sinusitis local anæsthesia

INGERSOLL, syphilitic pharyngeal stenosis .

106,278

273

IRSAI, scleroma

JACQUES and BerTemès, fibrous polypus .

$\mathrm{J}_{\mathbf{A Y}}$ (Melville), asthma.

JENKINS (G. J.), fractures of temporal bone Ménière's syndrome, operation and Cheatle (A. H.), exposed posterior semicircular canal

JoNES (H. E.), tonsil guillotine

Jouty, laryngeal tuberculosis

KAHLER, antral neoplasms

Katzenstern, phonation centres.

Krith (Prof.), remarks on displaced pituitary

KeLLY (A. Brown), myasthenia gravis syringobulbia

Kelson (W. H.), lupus of larynx.

neoplasm of pharynx

_____ neoplasm of tympanum

- - polypus of naso-pharynx tonsillar cyst

Kerrison (Philip D.), purulent labyrinthitis

KNIGHT (C. H.), black tongue

Koenig (C. J.), singer's' nodes

tonsillotomy, etc.

KOFFLER (Karl), tonsillectomy

KoLMER and WeSTon, searlatinal rhinitis

Kopetsky (S. J.). labyrinth surgery

- vaccine therapy in otitis

KYLE (J. J.), ear symptoms in general disease

Labouré (J.), adenoids 


\section{Index.}

LAN NoIs and JocoD, ozænatous otitis

LARGE (Seccord H.), tracheoscopy, etc.

LAUTMANN, adenoid operation

_ nasal syphilis

LaURens (P.), tracheal stenosis .

LAw (E.), epithelioma of naso-pharynx

LETO (L.), paralysis of sixth nerve

Levinstern (O.), chronic tonsillitis recurrent paralysis

LIEVEN, salvarsan

LITHGOW (J. D.), frontal sinusitis

Logan (J. E.), President's Address

Love (A.), diphtheritic paralysis

Love (J. Kerr), education of the deaf lateral sinus thrombosis

Löwe (Ludwig), nasal surgery

McCardie (W. J.), tracheal gumma

MacCoy (A. W.), tonsil operation

MacKenna (R. W.), ionic medication

McKeen (S. F.), death following diphtheria antitoxin $\quad . \quad$. $\quad 665$

McKenzie (Dan), blocking of nasal duct ..$\quad$. $\quad . \quad 215$

\begin{tabular}{llllll} 
M laryngeal papilloma &. &. &. &. & \\
\hline
\end{tabular}

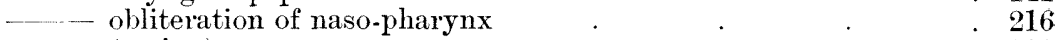

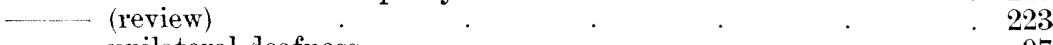
unilateral deafness

Maclay (Neil), endothelioma of frontal bone

MAнU (Georges), partial mastoid operation

Manasse (P.), typhoid deafness.

MARSCHICK, laryngeal cancer

Mathewson (G. H.), mastoiditis .

Mayer (Emil), œsophageal diverticula

Mayer (O.), otosclerosis

Meakins (J. C.), and Burkett (H. S.), vaccine treatment

Merrilu (W. H.), diabetic deafness

Metzen baum (M.), submucous resection

Meyer (A.), adenoids

Miluigan (W.), cerebellar abscess

injuries of external and middle ear . labyrinth fistula. labyrinth operation

Mrgnon, spasmodic rhinitis

MOORE (Irwin), frontal sinusitis

Mosher (H. P.), intubation of larynx

_- sinus exostosis

Moure, cancer of nose laryngeal cancer. naso-pharyngeal polypus

Mouret, dehiscences of ear, etc.

MUECKe (F. F.), aphonia

Mrles (Robert C.), salivary glands

Natrer (Marcel), ozæua

NeUManN, deafness for conversation 
OfFicer (D. McM.), septal deviation

ONODI (A.), embryonic cysts exposure of brain, etc. intra-cranial complications recessus frontalis

OPPIKOFER (E.), gangrene of larynx, etc.

Ouston (T. G.). radium .

Packard (F. R.), laryngeal papilloma

PAGE (J. R.), reflex neuroses

Palleine (Robert), nasal obstruction

Parish (B. D.), subcutaneous emphysema, etc.

Parker (Chas. A.), tonsillolith

Patterson (Norman), epiglottic cancer denture in œsophagus nasal chancre

Paunz (M.), typhoid laryngitis

Pegler (L. H.), aphonia in a boy .

- cancer of larynx .

_. laryngeal tuberculosis

-_ party-wall cancer pharyngeal ulceration

Peters (E. A.), nodules of vocal cord tonsillar cancer .

Philip, osteoma of antrum dentigerous cyst

Pierce (N. H.), surgery of pituitary

Pinder (T. H.), submucous resection

Pommerehne (F.), temporo-sphenoidal abscess

Porter (W. G.), labyrinthotomy .

- nystagmus of cord

Pow ELL (Fitzgerald), laryngeal neoplasm

Preysing, spongification of frontal sinus

Price-Brown (J.), cancer of nose, etc.

Prota (G.), pharyngeal occlusion .

Prowse (S. W.), fatal quinsy

REIK (H. O.), mastoid operation tobacco

REYNolds (F. E.), and FraSER (j. S.), ozæna and TURNer (A. Logan), mastoid suppuration

Richards (G. L.), silver nitrate in middle-ear suppuration

RICHARDSON (C. W.), epithelioma of larynx

Richardson (M. H.), cancer of tonsil

Rose (Frank), tuberculous tonsillitis

RUdLOFF (W.), extra-dural abscess

RUPPRECHT, tonsils and adenoids

Rutrin (E.), labyrinthitis

mucosus otitis

\begin{tabular}{ll}
\hline & mucosus otitis \\
meningitis \\
\hline-
\end{tabular}

SAFranek (J.), laryngeal lupus

\section{telangiectasis}

SCHAEFFER (J. P.), development of nose maxillary antrum

Schamberg (J. F.), epidemic chancre of lip

Schmiegelow (E.), laryngeal cancer 
SCHRÖTter, scleroma syringomyelia

SCHUbIGER, lateral pharyngitis

Scort (Sydney), fistula of labyrinth, etc.

SEwELL (Lindley), deafness from mumps labyrinth fistula .

Shambaugh (G. E.), blood-vessels of nose, etc. tone-perception .

Shearer (D. F.), noise machine.

SHURLY (B. R.), intubation

Srbley (W. Knowsley), teeth, etc.

Srems, atrophic rhinitis .

Sreur and Rouvillors, anæsthesia of larynx

— frontal sinus

SLUdER (G.), spheno-palatine ganglion

SMrTH (Harmon), laryngeal syphilis optic neuritis

Sмiтн (S. MacCuen), teaching of oto-laryngology

SMYrH (H. F.), lingual thyroid

SpIcer (Scanes), cancer of pharynx rigid resistances of larynx

STEIN (von), autokinesis, etc.

Stern (V. Saxtorph), wire-saw

STENGER, trauma of internal ear .

Stepinski, lactic acid

Strazza, wounds of thyroid cartilage

Strong (L. W.), thrombo-kinase .

Stuart Low (W.), cancer of nose cystic adenoma of parotid epithelioma of palate frontal sinusitis

Syme (W. S.), anæsthesia of palate, etc. frontal sinus operation sarcoma of nose .

Sxтschow (K.), laryngeal tuberculosis

Taptas, M. W. (rhinitis caseosa) .

Theisen (C. F.), lympho-sareoma of pharynx

Theobald (S.), reflex aural neuroses

Thompson (J. A.), bony ethmoidal eyst

Thomson (J. J.), quinsy, fatal

THomson (StClair), frontal sinusitis laryngeal epithelioma, stenosis nose and eye

Thost, laryngeal stenosis

Tiefenthal, operation on jugular bulb

TILLEY (H.), bronchiectasis from foreign body

bronchoscopy malformation of upper jaw

- nasal chisel

- pharyngoscope

- tooth in maxillary antrum uvular neoplasm

ToD (Hunter F.), ossiculectomy

Tratman (Frank), fibroma of larynx

TUNIs (J. P.), leukæmia, nasal abscesses

Turner (Logan), laryngeal tuberculosis meningitis, recovery

Reports of Ear and Throat Department 